\title{
MARKETING RESEARCH PROSPECTS FOR BIOENERGY DEVELOPMENT BASED ON USE OF WOOD FUEL
}

\author{
Zalesov Sergey \\ Ural State Forestry University for scientific research \\ USFEU, Yekaterinburg, Russia \\ t.e.v.16@yandex.ru
}

Opletaev Anton

Ural State Forestry University for scientific research USFEU, Yekaterinburg, Russia

Damary Roy

Institute of Business and Management "INSAM"

Geneva, Switzerland

\author{
Astratova Galina \\ Economics of housing and community amenities, and \\ energy department \\ Ural State Forestry University for scientific research \\ USFEU, Yekaterinburg, Russia
}

Pryadilina Natalia

Forest Business Economics Department

Ural State Forestry University for scientific research USFEU, Yekaterinburg, Russia

\author{
Kuklinov Mikhail \\ Ural State Forestry University for scientific research \\ USFEU, Yekaterinburg, Russia
}

\begin{abstract}
One of the youngest and most promising sectors of the Russian economy is bioenergy. Research of the Urals scientists shows that bioenergy based on wood fuel has several economic and technical advantages. These issues are considered in some countries as a question of priority fuel, especially in the framework of the Kyoto Protocol. Bioenergy development is especially important for Sverdlovsk region as the region is rich in forest (the forest cover in Russia is $\mathbf{6 8 . 6}$ percent). Therefore, for Ural region and Sverdlovsk region, in particular, the issues of processing wood waste into fuel and promoting the use of alternative sources of energy are more relevant than ever. The authors conducted a marketing research on the prospects of bioenergy development on the basis of the use of wood fuel. It is revealed that the categorical apparatus of marketing and market research in this industry is at a stage of active formation. However, for further effective development of bioenergy, it is necessary to intensify market research and creation of effective mechanisms of economic regulation. Bioenergy in Russia should be cost-effective and accessible to potential investors, producers and consumers.
\end{abstract}

Keywords- marketing, marketing research, green energetics, wood fuel, bioenergetics, pellets, briquettes, bioenergeticsmarketing research

\section{INTRODUCTION}

The problem of providing constantly growing needs of the global, national, regional and municipal economies in energy makes it necessary to develop renewable energy and, in particular, bioenergy. It is also condi-tioned by a solution of the global problems related to limited resources of the fossil fuels and environmental safety, that is, the implementation of obligations under the Kyoto Protocol [3].

Bioenergy is energy generated from biofuel. Such fuel may be different and is defined as derivatives from wood (woodchips, wood sawdust, etc.), straw bri-quettes, husk briquettes, briquettes from turn for paper, as well as biogas and liquid biofuels.

Bioenergetics is not an invention today. The fuels are used by mankind since ancient times. But in the course of time, biofuels were supplanted by such fossil fuels as gas, coal and petroleum. However, fossil resources become depleted and energetics history makes a turn, coming back to biological variants. The yielding of fossil fuels is measured in heating value; such variants have an essential plus because of their energy renewability.

Wood fuel is renewable, not bringing harm to the environment. During wood combustion, $90 \%$ is a harmless gas. Carbon dioxide is produced during wood fuel burning and causes the greenhouse effect. It is a natural part of the carbonate cycle and, therefore, the wood belongs to the environmentally friendly fuel.

Wood can be biofuel in the form of the wood chips, pellets, briquettes and firewood. Biomass, consisting of stem wood, bark, fir-needle or leaves, serves as a raw material for wood fuel production. The biomass can be subdivided into a biomass from major harvesting, improvement felling, left tree cuts, liberation felling and biomass from recycled wood. Mechanical pulp harvesting can be implemented when carrying out logging operations in a forest allotment, in the 
forest warehouse near roads, lower landing or at the enterprises of forest industry [4].

To use wood fuel, technological equipment for fuel combustion does not require serious modifications, and hazardous emission into environment is greatly reduced. Better heat transfer is achieved by burning granulated and pressed wood.

\section{QUESTION POSED ON A GLOBAL SCALE}

Bioenergetics based on wood raw material is one of the green energetics areas in a rapidly growing sector of global economy, based on wood biomass application. It has become a priority of the European Union (EU), the United States (US), Brazil and Canada's national econo-mies, in which programs and laws, designed to develop biofuel production, have been taken.

The issues of using the wood and waste wood with the aim of energy generation have been considered by the United Nations specialized agencies. The Department of Energy of the Eurasian Economic Commission (UNECE) and the UNECE Timber Committee analysed the trends and potential opportunities of using wood as a renewable energy source. It was established that in developed countries, the share of energy from wood in total energy con-sumption is not large. The share in the USA is $3.2 \%$, in Canada $-3.3 \%$, in France $1.8 \%$, in Germany - $0.9 \%$, in Austria - $1.3 \%$ and in Switzerland $-1.1 \%$.

The availability of the effective technologies is the main condition for implementation of bioenergy projects. The greatest success in developing such technologies has been achieved in Nordic countries such as Sweden and Finland (share of wood use for fuel of its total consumption is $19 \%$ and $21 \%$, respectively). In Nordic countries, unlike most countries of Western Europe, fuel chips are the main wood fuel in power supply activities.

In the total volume of wood use for fuel, the wood waste is $70 \%$, in the USA, Canada $-65 \%$, France $-28 \%$, Germany $62 \%$, Sweden $-51 \%$ and Finland $-3 \%$. In Denmark, where $18 \%$ of wood fuel is used, predominantly in the form of pellets, the highest energy efficiency indicators of the boiler plants in Europe have been achieved, with an average coefficient of efficiency of $89 \%$ [5].

In the European Union, there is a whole incentive system for manufacturers and consumers of different types of bioenergetics. The investments in bioenergy are exempt partially or completely from taxes; manufacturers of bioenergy are exempt from environmental taxes; enterprises passing on biofuel, receive subsidies for acquisition of equipment, etc. For countries developing the bioenergy sector of economy, not only the environmental component is important. Energy security is equally important. Bioenergetics provides such security because biofuel is produced domestically and is a renewable energy source. And BRICS countries, in particular Brazil, India and China are already rapidly developing power capacities [5].
Ecological compatibility, availability, low prices, power supply reliability and job creation are the main prerequisites that stimulate the development of bioenergy in the economically developed forest countries.

\section{QUESTION STATED ON A NATIONAL SCALE}

Despite the huge reserves of forest resources and all the advantages of wood fuel, the share of wood fuel in energy sector of Russia is less than $1.5 \%$.

The leadership of Russia is still betting on the development of nuclear, coal and large hydropower despite the fact that the sector of renewable energy is one of the most dynamically developing sectors of economy around the world. The Russian government plans only $4.5 \%$ of energy, using renewable energy sources by 2020 [6].

In Russia, there is no legislatively fixed way of stimulating the use of renewable energy sources. Adopted in 2011, the Law on Energy Saving and Energy Efficiency has little practical effect on issues of energy development of local renewable energy sources [7].

Lack of an effective mechanism for the return on investment through a tariff, high cost of the equipment and reconstruction discourage potential investors from active transition to biofuels (e.g. companies in the field of power engineering and enterprises with great potential of unused biomass). Furthermore, in some cases, the lack of a regulatory framework and inactivity of officials, or their reluctance to change anything also repel investors.

Russia has a significant potential for bioenergy development from wood waste. For example, pellet production is one of the most promising and actively growing segments of the timber industry complex as a whole. According to expert data, in Russia there is capacity in one form or another of more than 80 million $\mathrm{m} 3$. This huge, unclaimed, annually replenishing volume makes Russia a very interesting renewable energy market.

In the process of sawmill production in Russia, there are huge volumes of unused wood waste. Unscrupulous manufacturers were taking the chips to dumps and quarries and cause colossal damage to nature. To avoid this phenomenon, a system of special areas for collection of sawmill wastes was organized whereby producers of the sawn timber and other wood products are obliged to take the waste. One of the first such sites began to work in Arkhangelsk region and in the Republic of Komi. The system is supported by the regional government, and contravention of the established procedure leads to a fine of 500 thousand rubles. Briquette or pellet factories are being setup nearby the areas. In the Republic of Komi, briquettes that are supplied exclusively to municipal boilers are produced in such factories.

The creation of the domestic biofuel market is one of the priorities according to the "Comprehensive program for the development of biotechnology in the Russian Federation for the period until 2020" [8]. The task is now set to develop the bioenergy technological and technical base and develop 
demand for pellets and briquettes. This will facilitate decisionmaking on the establishment of the pellet and briquette production in the country by investors.

The largest producers of wood biofuel (pellets) with a production capacity of more than 50 thousand tons of pellets per year are: «Vyborgskaya lesopromyshlennaya korporatsiya» (Leningrad region), «Lesozavod №25» (Group of companies «Titan», Arhangelsk re-gion), «Vologdabioeksport» (Vologda Region), «TsentroVudKom» (the Republic of Komi), «Yenisey» and «Novoyeniseyskiy lesokhimicheskiy kompleks» (Krasnoyarsk region), «Baykal'skayalesnayakompaniya», «Forestinvest» (the Republic of Buryatia), «Setnovo» (Novgorod region).

Projects for the construction of large-scale pellet production based on large pulp and paper mills ( «Vy-borgskaya lesopromyshlennaya korporatsiya»), wood-working sawmills («Lesozavod №25», «Yenisey», «Setnovo»), as well as in the form of independent productions («Vologda bioeksport», etc.), have been successfully implemented in Russia [11].

The production of wood fuel in Russia is focused on external markets, which have the most attractive prices for biofuels. Export markets for Russia include Denmark, Italy, Great Britain, Lithuania, Sweden, Germany and other countries of the United Nations. In the medium term, Asian markets such as South Korea, Japan and China will grow in importance in terms of volumes.

Currently, the main investment activity in the production of pellets in Russia is shifting from the northwest towards Siberia. Among the plants planned or under construction capacities, there are not less than 100 thousand tons per year, notably in «Transsibirskaya lesnaya kompaniya» and the group of companies «Russkaya lesnaya gruppa» (Irkutsk region), «Aziya-Les» (Khabarovsk region), etc.

Nonetheless, the profitability of biofuel production in regions of the Siberian and Ural Federal Districts is lower than in the North-West and Central Federal Districts owing to the less convenient geographical position.

In 2015, a new certification program for industrial pellets, called SPB, was launched in Russia. For now, it is in the test mode. However, soon developers are planning to enter it without fail. Certification is undoubtedly an important component of a good business, but only large and mediumsized businesses can afford it. For small producers this is a problem, because a payback of this certificate is not at all obvious for the head of a small business. Therefore, in the near future some exits from the export market of pellet producers may be expected.

\section{QUESTION STATED ON A REGIONAL SCALE}

Sverdlovsk region is fuel-deficient because fossil fuel resources provide no more than 5 percent of its demand. Because of the constantly increasing cost of fuel oil, diesel fuel, coal and natural gas, there is a need to create a regional fuel industry based on local energy resources. A special role is given to wood as a renewable natural resource. The volume of wood waste in Sverdlovsk region exceeds 1.4 million cubic meters or about 800 thousand tons of standard fuel per year or about $700 \mathrm{MW}$ of thermal capacity [12].

The potential volume of wood waste in the region is not less than 4.5 million cubic meters. This includes unused noncommercially viable timber from improvement felling except for use as waste. This potential is in the form of logging residues, sawdust, chips, shavings, lump waste and bark, and small-scale timber from the felling. The use of this potential would allow full provision of heat and electricity to the majority of municipalities in remote areas that do not have centralized energy sources.

The cost of heat generation from wood fuel is 3 times lower than the cost of heat from fuel oil, 2.5 times lower than from coal, and 4-7 times lower than the cost of thermal energy produced by electrical installations. That is, the ecological advantages of wood fuel are obvious [12].

Municipal boilers on wood fuel basic ally use round wood, fuel chips, slab, and other sawmilling wastes of local forest users. The number of such boilers, according to the Ministry of Energy and Housing and Utilities of Sverdlovsk Region, is 305 units of the total number of municipal boilers $(2,327$ units), the amount of generated energy is 141,173 MW, and fuel consumption volume is 17.34 tons of standard fuel [5].

In recent years, 30 quite large pellet boilers have been launched, and about 100 small boilers on pellets and briquettes in the private sector of Sverdlovsk region. The region has about 20 companies producing pellets and briquettes.

Currently, a number of projects for the production of fuel pellets are being implemented by enterprises of Sverdlovsk region. The leading producers of fuel pellets in Sverdlovsk region are «Torgovo-promyshlennaya firma «YUT» (Settlement Kourovka of Pervouralsk urban district), «Koz'menko S.N.» (Verkhnyaya Tura), «Pelletnoyeteplo» (Ekaterinburg).

Presently, Sverdlovsk region has 55 boilers that operate on pellets with a total installed heat capacity of $3.5 \mathrm{MW}$. The fuel consumption of the boilers is 8.5 tons per day. A feature of the strategy for creating such productions in the region is an orientation mainly to consumption within the region, due to the high costs of shipment for export sales. So, a network of automated municipal boilers, which provide a heat production for given settlement, should be developed simultaneously with the production of fuel pellets [12].

In Sverdlovsk region, it is planned soon to create sites for wood waste collection. The local department of timber industry is already considering this project and is preparing the corresponding program. The use of wood raw materials will allow the industry to refocus on production with high added value. Moreover, the further development of this bioenergy type will create additional workplaces, as well as develop small and medium-sized businesses, and improve social living conditions of the population and ecology.

An example of successful pellet production companies in Yekaterinburg is «Pelletnoyeteplo», which has been operating on the market since 2006. In 2007, the company built and put into operation its own pellet factory, located in $80 \mathrm{~km}$ from 
Yekaterinburg, with a capacity of $2200 \mathrm{~kg} / \mathrm{h}$. This approach is very promising, profitable and popular for owners in the domestic sales market. At the moment, the employees of «Pelletnoyeteplo» have installed several hundred pellet boilers in Sverdlovsk region for shops, cottages, industrial bases and recreation centers. The company also supplies them with pellets. Over ten years, the company not only mastered pellet production and established the production of biofuel boilers, but also developed an entire consumer network. All wood pellets produced by the company are used exclusively in the region. The company declined to seek external markets because of high transport costs.

\section{ACTUAL MARKETING PROBLEMS}

Analysis of available literature [4, 5, 9, 10, 13-17, etc.] shows the marketing research on the prospects of bioenergy development on the basis of the use of wood fuel.

It should be noted also that today in the world, there are some hundred definitions of the marketing, any of which does not offer a satisfactory explanation of an essence of this phenomenon. However, use of incorrect, inexact terms leads not only to misunderstanding of essence of marketing as a social and economic phenomenon, but also to short-reception in practice of due effect from marketing activity. It is obvious that this situation is one of the essential factors causing insufficient efficiency of reforms carried out in Russia.

In the earlier researches [ 1,2 , etc.], the authors quite in detail investigated the main approaches to the category "marketing" definition, established the reasons of their emergence and possibility of "peaceful co-existence" of various definitions in modern conditions. At the same time, all definitions can be grouped in intrinsic filling as follows:

1. Marketing is a certain kind of activity.

2. Marketing is a philosophy of business.

3. Marketing is the science studying a consumer demand.

4. Marketing is a system of the organization of production and production sale.

5. Marketing is the social process directed to satisfaction of needs of people and the organizations.

6. Marketing is a concept of management.

In a context of the perspective, declared in this article, let us dwell on such group of definitions as: marketing is "the administrative concept providing market orientation of production and marketing activity of firms", or marketing is "the integrative function of management transforming needs of the buyer to the income of the enterprise", etc.

However, the authors have not found in the available literature any research regarding the definition of marketing and its features on the market of biofuels in general and wood fuel in particular. Obviously, this topic requires a deep study in the nearest future. One can also notice that research of the market of biofuels is very poor. This should be the subject of the authors' further research.

\section{CONCLUSION}

In conclusion, the world market of bioenergy based on the use of wood raw materials in the next 3-5 years will continue its upward trend. For example, the EU Directive proposes the countries in the EU to increase the share of renewable energy sources to $20 \%$ by 2020 . The development of the Russian bioenergy market based on the use of wood will also tend to grow, although not as actively as in the world. This can help to solve the problems of energy supply to small towns and villages with logging enterprises. In remote forest areas, the introduction of new technological production chains of forest raw materials for bioenergy will have a positive impact on the sustainable development of the regions [9].

One of the main tasks of regional bioenergy is the emergence of the new bioenergy plants based on the thermal processing of wood waste and low-quality wood in Sverdlovsk region.

An important issue is the attraction of investments in this industry. Potential investors may be interested in production development in the region due to availability of sufficient volumes of the low quality wood wastes for pellet production, an available work force and free production areas. At the same time, a network of boilers and the thermal power plants oriented to the consumption of this type of fuel should develop in parallel with pellet production.

The authors' opinion is that to continue the development of this market, the support with subsidies from the federal and regional authorities is needed. In Russia and Sverdlovsk region, budgetary funds need allocating for the construction of new biofuel plants and modifying boilers.

Let us not forgot that the complete transition of energy to bioenergy is impossible. An effective practice of "green energy" based on the use of wood fuel can however be achieved in specific market segments in combination with other structures of alternative and traditional energy.

\section{References}

[1] Galina V. Astratova and others, Market Research in the Ural Region, Conference Materials of the Participants of the U.S.A. Department of Agriculture Faculty Exchange Program (FEP) 1995 - 1998. Moscow. October 29-31, 2001, pp. 15-30, Washington D.C., April 2002.

[2] Galina V. Astratova, The Categorical Device of Marketing and its Role in Research of Attributes of Life Quality, The 3rd International Conference Economics and Management-Based on New Technologies. EMoNT-2013, 13-16 June 2013, Vrnjacka Banja, Serbia. 7 p.

[3] The Kyoto Protocol of the United Nations Framework Convention on Climate Change (Kyoto, December 11, 1997). Retrieved from at:http://base.garant.ru/ 12131392/\#ixzz3hMyCIpMS

[4] Wood fuel is an alternative to traditional energy sources, Belgiproles Belgiproles, 2008, no. 5, 60 p.

[5] A.A. Dobrachev, A.V. Mekhrentsev, N.A. Shpak, Resources of biofuel of the Sverdlovsk region and their use, Ural State Forestry Engineering University, 2015, $285 \mathrm{p}$.

[6] The decree of the government of Russian Federation dated 08.01.2009 no. 1-p (redaction from 28.05.2013) "On the main directions of the state policy in the field of increasing energy efficiency of the electric power industry based on the renewable energy use for the period up to 2020 "

[7] The federal law dated 23.11.2009 no. 261-FL "On the energy saving, and on the increasing energy efficiency and on the introduction of amendments to certain legislative acts of the Russian Federation" .

[8] A comprehensive program of the development of biotechnologies in the Russian Federation for the period up to 2020, Retrieved from http://base.garant.ru/70168244/\#ixzz4a55RB7Qu 
[9] Philip Kotler, Gary Armstrong,. Principles of Marketing, 6-th ed, New Jersey, A Paramount Communications Company, 1994, 692 p.

[10] Philip Kotler, Thas de Bes Fernando, Winning At Innovation: The A-toF Model, PalgraveMacmillan, 2011,272 p.

[11] The handbook of best available technologies and solutions for the production of wood pellets and briquettes from wood waste and also recommendations for the production of thermal and electric energy in the industrial and municipal energetics, taking into account the use of
wood
fuel.
Retrieved
from http://www.mnr.gov.ru/regulatory/detail.php?ID=131317

[12] The draft strategy for the development of timber industry of the Sverdlovsk Region for the period up to 2020. Retrieved from http://economy.midural.ru/sites/default/files/documents/lesoprom_komp 1.pdf
[13] E.N. Shcherbakov, S.P. Karpachev, A.N. Komyakov, A.N. Slinchenkov, The development problems of bioenergetics based on wood raw materials in Russia, Forest Herald, no. 4, p. 70, 2010.

[14] Leon G. Schiffman, Leslie Lazar Kanuck, Consumer Behavior, 4-th ed. New Jersey: Prentice Hall, Inc., pp. 800, 1991.

[15] R.M. Williams, American society: a sociological interpretation, NY: Knopf, pp. 397-420, 2001.

[16] J.Y. Wind, Product Policy: Concepts, Methods and Strategy, Reading: Mass., Adisson Wesley, 1982.

[17] J.Y. Wind, V. Mahajan, D.S. Swire, An Empirical Comparison of Standadized Portfolio Models, J. of Marketing, V. 47, pp. 89-99, 1983. 